\title{
11 Conducting research on ageing in the space of sensitive issues - as exemplified by domestic violence against the elderly
}

\author{
Matgorzata Halicka and Jerzy Halicki
}

\begin{abstract}
The chapter is devoted to problems related to conducting research on sensitive topics in a qualitative research paradigm. Polish literature lacks a precise definition of the term "sensitive topic", which is more often referred to as a "difficult topic". A sensitive topic that is presented in these considerations is violence against the elderly, with particular emphasis on elderly women. Under certain political conditions (e.g., in a totalitarian system) any research subject may become a sensitive topic. The researcher - in addition to their main role - can also support the elderly in seeking professional help. There were situations when the respondent expected help from us the researchers. Expecting such actions is referred to in Polish literature as "incorrect identification of the researcher". Knowledge from sources other than the interview may also be useful for a proper understanding of the research situation. These types of situations can be described as backstage phenomena and backstage knowledge. Satisfaction with the meeting and its effect in the form of an obtained interview are dependent on prudent empathy understood as dialog marked by patience, alertness, understanding and sensitivity (but not devoid of criticism?). Based on many years of research experience, we are convinced that the interview is in many cases a therapeutic procedure. Interviews can also take on an educational dimension. This occurs when the researcher delves into the personal micro-worlds and experiences of the subjects. This is accompanied by strong emotions that would not otherwise be revealed.
\end{abstract}

\section{Introduction}

There are subjects which are difficult to discuss even among friends. For example, it is not easy to tell others about violence experienced from a spouse. It is all the more difficult when this is chosen as a research subject. After all, in the context of research, we interact with strangers, who we expect to share their life experience, opinions and reflections.

The aim of this chapter is to present our thoughts on research into sensitive subjects. Our discussion will focus primarily on violence against the elderly. This subject is described as sensitive in literature (Renzetti and Lee, 1993; Dickson-Swift, James and Liamputtong, 2008; Elmir et al., 2011).

The authors of this chapter have conducted research together, but the interviews were conducted by one person. Therefore, some of the thoughts on specific situations will be described in third person singular.

\section{Defining sensitive subjects}

In English language literature one can find two categories describing the same problem: sensitive research and sensitive subjects. According to Joan Sieber and Liz Stanley 
(1988), socially sensitive research is research defined as "studies in which there are potential consequences or implications, either directly for the participants in the research or for the class of individuals represented by the research" (p. 49). Such a broad definition of sensitive research means that almost all social research may be described as sensitive (Dickson-Swift, James and Liamputtong, 2008). Sensitive research is usually described as research which is "intimate, discreditable or incriminating" (Renzetti and Lee, 1993, p. ix). Raymond Lee defines sensitive research as "research which potentially poses a substantial threat to those who are or have been involved in it" (1993, p. 4). This definition includes potential effects on both the subjects and the researchers. It is stressed that this take on the subject encourages research into the potential damage done to both the researchers and the subjects (Dickson-Swift, James and Liamputtong, 2008). It seems, however, that research into sensitive subjects may not lead to negative results only, but to positive ones too (Elmir et al., 2011).

Social research on sensitive subjects was initiated by sociologists from the Chicago school of sociology. Their research often concentrated around the family, friendship and the local community and often involved gaining access to the private lives of research subjects. According to M. Bulmer the researchers were not entirely aware of the methods they used, which allowed them to circumvent many methodological and ethical issues (DicksonSwift, James and Liamputtong, 2008).

Following the social changes of the 1960s and 1970s issues began appearing which went hitherto unnoticed, described as "perceived sensitivity". Researchers started to delve into issues of sexual behaviors, domestic violence or alcoholism, which were considered taboo in the 1970s and associated with sensitive research. This period also saw the beginning of feminist research, which involves, primarily, attempting to understand the experience of women in relation to power, dominance, unequal relations between genders (DicksonSwift, James and Liamputtong, 2008).

What in English literature is described as sensitive subjects, in Polish is often referred to as "difficult subjects". Trying to find a precise definition of "difficult subjects" in Polish scholarly literature is futile. M. Wojciechowska (2013, p. 245), writing about difficult issues has in mind "primarily those social issues which for various reasons research usually find difficult to access directly" [przede wszystkim te zjawiska społeczne które z rożnych względów sa na ogół trudno dostępne bezpośredniemu poznaniu badaczy]. They fit - in the author's opinion - into apparent reality, but also function in the hidden realm, which is hard to access for researchers. Difficult issues, although not the easiest to observe directly, are all the more interesting for scholars because of that (Ślęzak, 2009). Marta Makowska (2013) describes difficult issues as thorny and in her work invokes the definition created by Clary Renzetti and Raymonda Lee. The broadest understanding of difficult issues was presented by Sylwia Męcwel (2012), who frames it as difficult problems, difficult research terrain and difficult methods. In her article she also invokes a wide range of literature implicitly and explicitly discussing "difficult" problems. The term "difficult subjects" is also often associated with the category of "hidden issues", which often comes up in literature and is understood as "social actions which are hidden by their subjects out of fear of sanctions" [takie działania społeczne, które sa przez podejmujace je podmioty ukrywane w obawie przed sankcja] (Gurtowski and Waszewski, 2009, p. 168). The discussion of difficult subjects taken up in Polish scholarly literature concentrates on two areas: methodological (e.g., Przyłuska-Fiszer and Wójcik, 2009; Ślęzak, 2018) and ethical (e.g., Mizielińska et al., 2018; Izdebski and Łukaszek, 2018). 
The reason why there are no broader efforts into defining the term "difficult issues" in our culture is - as it would seem - the use of this particular term. The word "difficult" is fairly obvious in its perception. It needs no further explanation in Polish. However, the perceptions of the word "sensitive" is different. Its meaning is blurry enough that it needs further narrowing.

Sensitive subjects will be exemplified by our experience derived from conducting empirical research on violence against the elderly, including elderly women. For those reasons we owe the readers a few sentences about the research on violence against the elderly. However, in order to go deeper into the problem we are interested in - that of conducting research into sensitive subjects - we will also draw on the experience and observations from other research areas.

\section{Gerontological research into sensitive subjects, as exemplified by domestic violence}

Abuses against the elderly have for many years not been seen as a social problem. First clinical descriptions of maltreatment of the elderly started appearing by the end of the 1930s (Bonnie and Wallace, 2003). From the mid-1950s abuses against the elderly started to be treated as a serious social issue. This was associated with changes in familial relations, which resulted in the elderly being less able to rely on the aid and support of their children and grandchildren (Anetzberger, 2008). Abuses against the elderly became a matter of public debate by the end of the 1970s and the early 1980s. The discussion was inspired by the publications of geriatrician R. Butler and sociologist S. Steinmetz. The former wrote in 1975 about the "abused elder syndrome", while the latter was the author of the testimony made in front of the House Science and Technology Committee (USA), which was based on the results of the research that had been conducted in 1978 on the thus far neglected aspects of domestic violence (Anetzberger, 2008). As it was brought to attention in the 1970s the problem of violence against the elderly in the USA immediately began to be studied and explained, while the search ensued for solutions (Penhale, 2010).

In Europe, one of the first mentions of the subject was a letter to the editors of the British Medical Journal, written by a physician at the Southmed Hospital in Bristol, G. R. Burston, and published in 1975 (Burston, 1975). The problem started being treated seriously in Great Britain in 1988, although it had already been noticed in the 1970s (Penhale, 2010). In the 1980s in the USA and some European states research was undertaken into violence against the elderly and prevention (Lowenstein, 1995).

Currently, after over 30 years since systematic research into violence against the elderly started, one can confidently state that this very important issue has been treated with the appropriate seriousness by scholars and received significant attention in literature.

In Poland, the problem of violence against the elderly was not analyzed in many works in the twentieth century. It came up rarely and tangentially to other problems, such as intergenerational conflicts. Particular attention should be paid to the work of J. Piotrowski (1973) and B. Synak (1976). The first systematic research into the elderly as perpetrators and victims of pathological behaviors was conducted in Białystok at the turn of the 1980s and 1990s (Halicka, 1997, 1996, 1995).

Interest in violence against the elderly in Poland increased in the first decade of the twenty-first century. Various research methods were used. Research was done based on quantitative (Pędich, 2002) and qualitative methods (Orzechowska, 2000; TwardowskaRajewska and Rajewska-de Mezer, 2007; Maćkowicz, 2015), as well as analysis of medical 
and nursing documentation (Rudnicka-Drożak and Latalski, 2006). Some of the research was also conducted as part of international research projects (Tobiasz-Adamczyk, 2009; Halicka and Halicki, 2010: Halicka et al., 2015, 2017). These publications contain a full literature overview on the subject of violence against the elderly in Poland.

\section{Difficulties in conducting research into sensitive subjects concerning the elderly}

One of the sensitive issues which will be treated as the point of reference for this work is domestic violence against the elderly. From the point of view of the empirical research done in this area it is a challenge for both the researcher and the subjects. We understand sensitive research as $\mathrm{R}$. Lee does: as research which can potentially be a serious threat to those who are or were involved in it (Lee, 1993). By discussing the difficulties researchers face when conducting research of this type we will invoke - as was mentioned - mostly the issue of violence. However, this will not be the only point of reference for this work. To encourage readers to take an interest in the issues discussed in this work and the experience we have derived from our research, we will attempt to also reference other important and sensitive subjects. Following the thoughts of the aforementioned R. Lee, we agree with the author that as research is done into sensitive subjects there is potentially a risk in three areas. The first is the risk of invasiveness understood as intruding on the private, intimate world of the subject. Another type of threat is the risk of sanction should the research results be stigmatizing or aggravating, for example in the case of interviews with drug addicts and leaking sensitive information. The third potential risk is a political one, for example related to some social conflict (Lee, 1993). By characterizing sensitive research as that which is a potential threat, the author has in mind a threat which has its source in the studied problems. However, this definition cannot be applied to the specific socio-political situation in the studied geographical area. This is well illustrated by the following example. In 2005 we conducted interviews in the Republic of Belarus. The Belarusian researcher who was cooperating with us was unable to obtain permission to conduct the interviews from the authorities. Since we had the consent of the subjects, we decided to conduct research without the authorities' permission. This situation changes every subject into a sensitive one, because revealing the fact that the research was conducted would be a threat to both the researchers and the subjects.

Taking this into account we claim that some research into sensitive subjects will be more risky than others, while others may involve potential benefits to both the subject and interviewer. However, one should note that every person has a different private sphere, a different level of sensitivity. Furthermore, the perception of sensitive subjects depends largely on the culture in which one was brought up and identifies with, on their personal situation, their age, gender and finally on the interviewer. Below we will present our own experiences and difficulties we have encountered in conducting research into sensitive subjects.

\section{Our own approach to research into sensitive subjects}

The qualitative research into sensitive subjects which we have conducted in Poland over the years concentrated on various research areas. Over the last decade-and-a-half they focused on the problem of violence against the elderly. In our experience, this type of research is a challenge to both the researcher and the subject. Various situations demand 
scholars to enter different roles and there are no clear rules of conduct - the researchers make decisions and adopt strategies on their own. However, they must pay heed to methodological and ethical concerns. Responsible conduct requires scholars to face ethical questions, which result from face-to-face contact (Babbie, 2007).

The research situation may give rise to doubts, dilemmas and sometimes even a sense of guilt both in the scholar and the subject, but this type and character of empirical research, considering its subjects are the elderly, can also have a supportive, therapeutic character, especially for victims of domestic violence. Many of them lack expertise on the kinds of help and formal professional support they can receive. Aside from their main role, researchers may clearly and intelligibly explain to the elderly where and how they can gain access to professional, formal aid.

Conversations with research participants on sensitive subjects require skill, research and life experience, as well as the appropriate interview techniques, because studying problems such as violence may cause pain and discomfort to the victim. As a researcher one has the chance to not just observe, but also to participate in the biographical experience of the subjects. Elderly who experience violence, in particular women, can be considered a special category of research subjects. Their knowledge based on life experience is priceless. However, when it comes to sensitive subjects, there are usually strong emotions involved: shame, humiliation, sacrifice, fear for the future. Would a different form of conversation, maybe more informal, maybe more discreet, be better at managing the emotions of the subjects? According to Babbie, conducting interviews requires the skill of attentive listening and the ability to discreetly direct the conversation (Babbie, 2007).

Scholars of sensitive subjects should bear in mind the unintended consequences of their research. Research subjects may see researchers as a source of material gain, connections and prestige, which has nothing to do with the research process or objectives (FrankfortNachmias and Nachmias 2001). It happens occasionally that a person who falls victim to violence expects help from the scholars. In one of the interviews, which were part of our research, the interviewee expected help in finding temporary accommodation, so that she could move away from her abusive husband. Even after the study had ended she remained in contact with the interviewer, whom she asked repeatedly for help. In Polish scholarship such situations are referred to as false identification of the researcher (Borucka, 1992). We believe that false identification of the researcher is a peculiar way of finding help, maybe more confidential, discreet, maybe causes less shame to be brought on by the domestic violence and lack of expertise on how to deal with the situation. Such an attitude is characteristic of strong people, who are willing to fight for themselves, who take advantage of any chance to change their situation. However, our research indicates that women with this attitude are decidedly a minority.

Social workers who worked with us claimed that a sensitive interview delves into the personal traumas of the victim. Based on our extensive research experience we can state with some conviction that an interview can bring out old traumas for some people, but in other cases it may be quite therapeutic. For many people we talked to about the violence in their families the conversation caused gratitude for the meeting, where they could finally unburden themselves. We would like to note here the role that is played by the scholar in researching sensitive subjects. In the case of violence against women the researcher should be a woman, preferable married, middle-aged, with children, who has life experience. Her own life experience allows her to have a broader view of sensitive subjects. This was also noticed by other Polish scholars (Czekanowski, 2018). 
Another thing we have noticed in our research is the problem of interpreting the collected data correctly. It would happen that a male police officer sided with the male perpetrator of violence. We present below an example of such a situation. A female victim of domestic violence noted the lack of reaction from the police officer when she accused her husband. The husband, a trained psychologist, manipulated others by spreading false information about his relations to his wife. To her surprise the police officer did not believe in her story, but was more likely to believe her husband and refused to open the so-called Blue Card procedure. ${ }^{1}$ This procedure was only put into motion after a visit from a female officer who was standing in for the usual policeman. She believed in the victim's version of events. It turned out that the local officer was recently abandoned by his wife and was distrusting of a woman's statement. Therefore, in order to understand the situation correctly and undertake appropriate corrective actions one needs to obtain knowledge from sources other than an interview. This type of situation can be described as phenomena and knowledge from behind the scenes - a phrase which appears in Polish literature (Gurtowski and Waszewski, 2009). Obviously, from the point of view of a scholar the objective is to understand the micro-universe of the woman revealed through her narration. However, it is also important to be aware that the research should serve a greater purpose than just knowledge and understanding.

\section{Conduct in empirical research into sensitive subjects}

Since sensitive subjects can be associated with a significant risk to the participants of the research and cause intense emotions, such as sadness o embarrassment, one should tread carefully within the space of empirical research. A researcher's ability to build a relation with the participant and gain their trust is the basis for the research. We suggest that in sensitive cases one should be cautiously empathetic. Being overly rigorous is ill-advised.

Satisfaction with a meeting and its effect in the form of a successful interview is dependent on cautious empathy. As an example we can invoke one of the interviews we conducted with an elderly man who was dissatisfied with his life, as part of a research project on life satisfaction among the elderly. The co-author of the article tried to meet with the interviewee twice, with no success. Despite having arranged the date and time of the interview over the phone, the subject was not at home. She was only successful on her third attempt. The researcher, who was then visibly pregnant, was late for the meeting, even though she did not intend to. However, with the benefit of hindsight, she believes this was a positive thing. The man opened his door and, seeing a middle-aged pregnant woman, invited her in. Establishing a relationship was difficult at the beginning, the man was quiet, spoke in half-sentences, unwillingly. At first glance he seemed stone-faced, cold, reserved around others, unwilling to make contact, distrustful. However, as the conversation progressed his armor melted and a breakthrough happened after some 15-20 minutes. He was visibly moved, cried, and the researcher entered a new realm of difficult events and the man's traumatic experiences associated with them. Opening up, he entrusted many personal secrets to the researcher, which he had so far, as he claimed, not told to anyone. Heavily burdened by a difficult life, rarely smiling, very sensitive. At the end of the 4.5 hours of recorded conversation he expressed his happiness and gratitude for it. For the coauthor of the presented work it was also an exceptional enriching, if difficult, experience. Although it seems that in this case one can talk about cautious empathy, it was nevertheless difficult for the researcher to distance herself from the subjective experience of the interviewee. If researchers become too involved in the life of the subjects, they may be moved 
by their personal problems and crises. This issue has to be acknowledged and faced (Babbie, 2007). In such cases researchers might themselves be traumatized, as was discussed by Dunkley and Whelan (2006).

The aforementioned personal experience of a research case indicates that haste is not advisable, if there is a possibility that the time of the interview may significantly increase. One should bear in mind that if the interviewee "opens up", is keen to talk and to make personal confessions, they become submerged in their autobiography and lose a sense of time, which is beyond their control in such situations. If the researcher does not hasten the speaker and reacts appropriately to the situation in a balanced and sensitive manner, they may obtain rich, valuable research material. For the interviewees talking about themselves and the chance to be heard is helpful and provides a sense of relief. From this extremely valuable interview we can draw more conclusions, that is, that it is good to be able by the end of one's life to express one's pain and burdens, and what has hitherto been kept secret. This is yet another reason why the study of sensitive subjects is necessary. When, after many years, we remember those that we once talked to, their memory is still alive and the emotions still vibrant. As a research task this was a difficult experience for us, but at the same time it enriched us not only as scholars but, more importantly, as people.

Another important step toward handling empirical research into sensitive subjects is patience and caution. If a participant is impatient with the interview or its subject, one should react delicately, carefully and with care, because one never knows what is the cause of such a reaction. Time to reflect is necessary. It becomes an ally to the relation between the scholar and the subject. Let us use as an example an interview, which we conducted with a woman with low life satisfaction. This was a very difficult but short interview, lasting only 45 minutes. She had communicative and interpersonal problems and was secretive, withdrawn, one could say she was not fully present at the interview. She was, as would later turn out, permanently traumatized, which was the result of wartime experiences, in particular the medical experiments Fascists conducted on her, which left her infertile. These experiments left permanent scars in her psyche. Psychologists claim that after suffering through a traumatizing experience, a person may experience dissociative symptoms, relive the event, avoid stimuli that remind them of the event, experience fear and have a limited capacity in social and professional life (Widera-Wysoczańska, 2011). Not all stories, even those told in detail and in depth, can be cathartic and bring relief. Everyone perceives and experiences events subjectively. The meaning that one associates with such situations depends on an individual's unique life history. Understanding somebody's life is being aware that it is separate from fate. It also involves reaching into the complicated network of connected factors, which lead to the uniqueness of everyone's life experience (Bauman, 2010). In these and similar cases one should strive to create the conditions allowing one to identify ways of avoiding permanently traumatizing the subject. However, if we are to find out about such situations regarding people at the end of their lives, one has to ask if this is indeed at all possible.

We would also like to pass on some of our reflections on the reliability of the obtained research material. There may be situations when conducting face-to-face research into sensitive areas turns out to be difficult for the subjects, who may be embarrassed by the interview. Our research experience also indicates that if appropriate research conditions are created, based on trust between the subject and the scholar, there is no risk of this happening. Furthermore, when starting research one should assume that if a person agreed to an interview, the information obtained from them will be true. We want to stress that elderly research participants are a specific category of subjects. Work with them is very rewarding: 
they are humble, honest and seek relief in conversation. If there is a relation of trust during an interview, it can be a therapeutic, cleansing experience, which gives the interviewee a chance to express hidden negative emotions which have accumulated over years of often difficult, sensitive, embarrassing or traumatic personal experiences.

Another issue connected with conducting research into sensitive subjects is the question whether it is ethical to discuss certain subjects and expose an elderly to pain, bad memories and negative experiences. Based on our own experience as researchers studying social subjects involving the elderly, we claim that in some situations, such as permanent trauma, there may be a risk of further injury. However, in most cases, a return to the past and difficult memories is not an invasive threat, even though it delves into the personal and mysterious and releases emotions. The personality of the researchers is very important. If they respect the dignity of the subject and display expertise, if they do not force the conversation, there is little threat of injury. The elderly often need to talk. Negative emotions, which they (particularly women) have often been suppressing for years, influence their psychological health, which is often reflected in their everyday behaviors.

Another important reflection associated with studying difficult subjects relating to the elderly is that they are at the end of their lives and have a host of experiences. Considering their lives and its balance they may come to the conclusion that if they do nothing for themselves, or for a cause, they might never have the chance to do it. A female victim of violence may take steps toward freeing herself from her husband-tormentor. Agreeing to participate in research into sensitive subjects increases our understanding and may result in new social practices. The elderly who agree to an interview do this consciously, responsibly and honestly.

Another thread of research into sensitive subjects and its practices may relate to death and dying. It is hard to create a research relationship with a person experiencing a limited situation. We invoke with nostalgia and emotion the memories of one interviewee, who was, at the same time, aware of his slow passing and with a great will to live and hope for another meeting, which would allow him to save from oblivion that which was in his life valuable and precious - his memories. He was at peace with his mortality but also glad to be able to share his experiences before death. He felt the need to go back to his past, which he remembered in great detail. In terms of verbal communication this was a beautiful, lively, thrilling, enriching tale of a dying man. He also talked about his sickness and discussed issues of finality. He wanted to share at least a part of his life. We were waiting for another meeting, but death took him earlier. We never completed the interview, because he did not live to have another meeting. This was an exceptional interviewee, who was for the researcher not just a source of knowledge, but also education. In subject literature it is stressed that diving into the individual micro-worlds and experiences of the subjects may lead to deep emotional reactions, which might otherwise never come to light (Cowles, 1988).

Additional reflections derived from our research, which may also turn out to be useful to other scholars delving into qualitative research are related to the research team. If more than just the narration of a victim of violence is to be interpreted, but the whole situation of violence, it is good for the analysis to be conducted by a mixed gender team. In our case this helped us distinguish situations of violence from those of conflict.

We would also like to note that problems may arise associated with recording the information obtained in an interview. This may lead to resistance from the elderly. Our use of a voice recorder in our research caused certain reservations. We noticed this both in our research in Belarus and in Poland. Some women were willing to talk about the violence 
they were experiencing, but would not agree to recording the conversations, only allowing interviewers to take notes. This information was used as factual. This material was treated similarly to how the police treat evidence in an investigation.

We also have some thoughts on research methodology. In literature it is often written that sensitive subjects should be studied using qualitative methods. Does a problem stop being sensitive if quantitative methods are used? In our experience, for example, when young people talk about their alcohol consumption, some answers are clearly dishonest. It is different when they talk about alcohol consumption in their age group. Therefore, the way research questions are posed can also make an issue sensitive.

\section{Conclusion}

In order to learn about and understand social realities and various problems therein, it is necessary to undertake the study of sensitive subjects. We are aware that this is not an easy task, but it is necessary. We as scholars bear the responsibility for recognizing and understanding social realities. Sensitive research often relates to important, burning social issues.

Many years ago at one of our sociological conventions in Poland a renowned professor, Piotr Sztompka, entreated the participants to have the courage to take up difficult research subjects. It is with some satisfaction that we note today that this research is being done. And even though they are still small in scale, we believe that Polish scholars' scientific curiosity and courage to take up sensitive subjects will lead to both academic and utilitarian results. According to Antoni Sułek, social science is increasingly becoming an applied science - not just in planning and politics, but also in many areas of social practice. The author encourages sociologists and social scholars to have open minds and follow their "scientific conscience" (Sułek, 2002).

\section{Note}

1 In Poland the Blue Card procedure is opened by the police or social services in cases of domestic violence.

\section{References}

Anetzberger, G.J. (2008). Elder abuse. In: C.M. Renzetti and J.L. Edleson (eds), Encyclopedia of interpersonal violence. Vol. 1. Thousand Oaks, CA: Sage.

Babbie, A. (2007). Badania spoleczne w praktyce. Warszawa: Wydawnictwo Naukowe PWN.

Bauman, Z. (2010). Refleksja końcowa o pisaniu, o pisaniu socjologii. In: N.K. Denzin and Y.S. Lincoln (eds), Metody badań jakościowych. Vol. 2. Warszawa: Wydawnictwo Naukowe PWN.

Bonnie, R.J. and Wallace, R.B. (eds) (2003). Elder mistreatment: abuse, neglect, and exploitation in an ageing America. Washington, DC: National Academies Press.

Borucka, K.M. (1992). Specyfika wywiadów kwestionariuszowych z chorymi na raka: Analizy i próby technik badawczych w socjologii. Vol. IX. Warsaw: IFiS PAN.

Burston, G.R. (1975). Granny battering. British Medical Journal, 3, 592. doi.org/10.1136/ bmj.3.5983.592-a.

Cowles, K.V. (1988). Issues in qualitative research on sensitive topics. Western Journal of Nursing Research, 10(2), 163-179.

Czekanowski, P. (2018). Dylematy w badaniach opiekunów rodzinnych ludzi starych: Refleksje socjologa starości i opiekuna. Pedagogika Społeczna, XVII(3), 81-90.

Dickson-Swift, V., James, E. and Liamputtong, P. (2008). Undertaking sensitive research in the health and social sciences: managing boundaries, emotions and risks. Cambridge: Cambridge University Press. 
Dunkley, J.A. and Whelan, T. (2006). Vicarious traumatisation: current status and future directions. British Journal of Guidance and Counselling, 34(1), 107-116.

Elmir, R., Schmied, V., Jackson, D. and Wilkes, L. (2011). Interviewing people about potentially sensitive topics. Nurse Researcher, 19(1), 12-16.

Frankfort-Nachmias, C. and Nachmias, D. (2001). Metody badawcze w naukach spolecznych. Warszawa: Wydawnictwo Zysk i S-ka.

Gurtowski, M. and Waszewski, J. (2009). Redukcja do jawności: O pomijaniu zjawisk zakulisowych w badaniach socjologicznych. In: B. Aneta and L. Kubisz-Muła (eds), Metody, techniki i praktyka badań społecznych. Bielsko-Biała: Wydawnictwo Naukowe Akademii Techniczno-Humanistycznej w Bielsku-Białej.

Halicka, M. (1995). Elder abuse and neglect in Poland. Journal of Elder Abuse and Neglect, 6(3-4), $157-169$.

Halicka, M. (1996). Człowiek stary jako ofiara nadużyć. In: B. Szatur-Jaworska (ed.), Prawa obywatelskie ludzi starych $w$ Polsce a europejskie deklaracje praw człowieka. Białystok: Polskie Towarzystwo Gerontologiczne.

Halicka, M. (1997). Nadużycia i zaniedbania wobec osób starszych. In: M. Malikowski (ed.), Problemy społeczne w okresie zmian systemowych w Polsce. Rzeszów: Wyższa Szkoła Pedagogiczna.

Halicka, M. and Halicki, J. (eds) (2010). Przemoc wobec ludzi starych. Białystok: Wydawnictwo Temida 2.

Halicka, M., Halicki, J., Kramkowska, E. and Szafranek, A. (2015). Law enforcement, the judiciary and intimate partner violence against the elderly in court files. Studia Socjologiczne, 2, 195-214.

Halicka, M., Halicki, J., Kramkowska, E. and Szafranek, A. (2017). Kobiety doświadczające przemocy $w$ rodzinie $i$ ich ochrona: Aspekty prawne i społeczne. Białystok: Wydawnictwo Uniwersytetu w Białymstoku.

Izdebski, Z. and Łukaszek, M. (2018). Etyczne aspekty badania przemocy seksualnej: Dziecko Krzywdzone. Teoria, badania, praktyka, 17(2), 117-146.

Lee, R. (1993). Doing research on sensitive topics. Thousand Oaks, CA: Sage.

Lowenstein, A. (1995). Elder abuse in a forming society: Israel. Journal of Elder Abuse and Neglect, 6(3-4), 81-100.

Maćkowicz, J. (2015). Osoby starsze jako ofiary przemocy domowej: Ujęcie wiktymologiczne. Kraków: Impuls.

Makowska, M. (2013). Prowadzenie wywiadów swobodnych na tematy drażliwe: przykład badań nad etyką pracy przedstawicieli medycznych. Dyskursy Młodych Andragogów, 14, 287-304.

Męcwel, S. (2012). Problemy badań terenowych: wybrane kwestie metodologiczne, praktyczne oraz etyczne przy badaniu zjawisk "trudnych". Przeglad Socjologiczny, 61(1), 155-178.

Mizielińska, J., Stasińska, A., Żadkowska, M. and Halawa, M. (2018). Dylematy etyczne w badaniu pary intymnej: Doświadczenia z pracy badawczej. Studia Socjologiczne, 3, 71-100.

Orzechowska, G. (2000). Człowiek stary ofiara przemocy w rodzinie. Rocznik Andragogiczny, 101-107.

Pędich, W. (2002). Regionalne zróżnicowanie sytuacji ludzi starych na wsi. In: B. Synak (ed.), Polska starość. Gdańsk: Wydawnictwo Uniwersytetu Gdańskieg.

Penhale, B. (2010). The concept of elder abuse: breaking the silence. In: M. Halicka, J. Halicki and K. Czykier (eds), Zagrożenia w starości I na jej przedpolu. Białystok: Wydawnictwo UwB.

Piotrowski, J. (1973). Miejsce człowieka starego w rodzinie i społeczeństwie. Warszawa: PWN.

Przyłuska-Fiszer, A. and Wójcik, A. (2009). Problemy metodologiczne badań naukowych w opiece paliatywnej. Diametros, 19, 119-131.

Renzetti, C. and Lee, R. (eds) (1993). Researching sensitive topics. Newbury Park, CA: Sage.

Rudnicka-Drożak, E. and Latalski, M. (2006). Rodzaje przemocy wobec kobiet po 65 roku życia. In: J.T. Kowaleski and P. Szukalski (eds), Starość i starzenie się jako doświadczenie jednostek $i$ zbiorowości ludzkich. Łódź: Uniwersytet Łódzki.

Sieber, J. and Stanley, B. (1988). Ethical and professional dimensions of socially sensitive research. American Psychologist, 43(1), 49-55. 


\section{M. Halicka and J. Halicki}

Ślęzak, I. (2009). Metodologiczne problemy badań nad zjawiskami "trudnymi” na przykładzie prostytucji. In: A. Bąk and Ł. Kubisz-Muła (eds), Metody, techniki i praktyka badań społecznych. Bielsko-Biała: Wydawnictwo Naukowe Akademii Techniczno-Humanistycznej w Bielsku-Białej.

Ślęzak, I. (2018). Praca nad zaufaniem: Etyczne, praktyczne i metodologiczne wyzwania w relacjach badacz-badani na przykładzie etnografii agencji towarzyskich. Przeglad Socjologii Jakościowej, XIV(1), 138-161.

Sułek, A. (2002). Ogród metodologii socjologicznej. Warszawa: Wydawnictwo Naukowe Scholar.

Synak, B. (1976). Problemy starych rolników. Warszawa: Ludowa Spółdzielnia Wydawnicza.

Tobiasz-Adamczyk, B. (ed.) (2009). Przemoc wobec osób starszych. Kraków: Wydawnictwo Uniwersytetu Jagiellońskiego.

Twardowska-Rajewska, J. and Rajewska-de Mezer, J. (2007). Samotność osób starszych jako czynnik ryzyka nadużyć strukturalnych. In: A. Horbowski and J. Potoczny (eds), Edukacja i animacja społeczno-kulturalna dorostych: Diagnoza - potrzeby - prognoza. Rzeszów: Wydawnictwo Uniwersytetu Rzeszowskiego.

Widera-Wysoczańska, A. (2011). PTSD “proste” i "złożone” jako konsekwencje zdarzeń traumatycznych u osób dorosłych. In: A. Widera-Wysoczańska and A. Kuczyńska (eds), Interpersonalna trauma: Mechanizmy i konsekwencje. Warszawa: Difin SA.

Wojciechowska, M. (2013). O wyzwaniach w badaniach trudnych zjawisk: Metodologiczne aspekty badań terenowych na przykładzie prostytucji kobiecej. Dyskursy Młodych Andragogów, 14, 245-267. 